\title{
Data on Creative Industries Ventures' Performance Influenced by Four Networking Types: Designing Strategies for a Sample of Female Entrepreneurs with the Use of Multiple Criteria Analysis
}

\author{
Naoum Mylonas ${ }^{1}$, Panagiotis Manolitzas ${ }^{1, *}$ and E. Grigoroudis ${ }^{2}$ (1) \\ 1 Department of Tourism, Ionian University, 49100 Corfu, Greece; naoumyl@gmail.com \\ 2 School of Production Engineering and Management, Technical University of Crete, 73100 Chania, Greece; \\ vangelis@ergasya.tuc.gr \\ * Correspondence: pmanol@ionio.gr
}

Received: 14 January 2020; Accepted: 7 March 2020; Published: 11 March 2020

check for updates

\begin{abstract}
This paper presents data that investigates the creative industries ventures' performance affected by four different types of networking, namely the social, the professional, the family, and that with public sector organizations. Three hundred and seventy-one questionnaires have been collected for the assessment of networking impact on venture performance. In order to examine the ventures' performance levels of the female entrepreneurs or self-employed in the creative industries of Greece, we use a multiple criteria method. Based on the data analysis, the most important criterion for the female entrepreneurs in the creative industries to perform highly is professional networking while the least important is observed in the criterion of family networking.
\end{abstract}

Dataset: The data is submitted as http://www.mdpi.com/2306-5729/5/1/24/s1.

Dataset License: CCO.

Keywords: venture performance; networking; creative industries; multicriteria analysis

\section{Summary}

The scope of the current survey is to assess the impact of four different types of networking on the ventures' performance in the field of creative industries. The importance of creative industries has been recognized during the 1990s as the economies moved away from the production of goods and services to the ideas and knowledge generation [1,2]. Gradually, several sectors have been incorporated in the creative industries due to the increasing importance of the domain on economic development [3-5]. Among the variety of existing classifications of the creative industries sectors, this study relies on the recent and quite inclusive definition by the European Cluster Observatory [6]. These sectors are Art Gallery, Architecture and Design, Graphic and Industrial Design, Sculpture, Publishing, Painting, Social Media, Advertising, Theatre, Film, Music, Fashion, Photography, Crafting and Antiques. In addition, the notion of entrepreneur in creative industries seems as quite complex, due to the specific nature of artists' and creators' personality. Thus, entrepreneurial activity in the creative industries faces a paradox between the spontaneous, unpredictable, and incompatible nature of creative work versus the strict rules and timetables and the nature of business which entails management, programming, and structuring of the creative production $[7,8]$. This survey examines a sample of female entrepreneurs in creative industries, because women have a stronger tendency to exert entrepreneurial 
activity in creative industries as they are induced more by creativity, rather than innovation in which males are dominant [9-12].

Moreover, creative industries are viewed as a favourable domain for women to establish small firms and under this vein to encourage their access to economic and employment reality. Prior research in the entrepreneurship field has revealed the importance of networking on conventional ventures' performance [13,14]. A significant part of these studies, indeed, focus on social network ties and professional or business network ties. Social network ties are formed between entrepreneurs and local community actors, as well as local social peers [13], while professional ties are developed with customers, suppliers, and competitors within the same industry $[13,14]$. Network ties are expected to be critical for the performance of creative industries firms, due to the limited sources to attract funds for their operation and their relatively small size $[15,16]$. It is worthy to be mentioned that only two studies $[17,18]$ attempted to explore the impact of networking on creative industries ventures' performance.

The novelty of this study is to reveal how four different network ties practiced by female entrepreneurs in the creative industries impact on their ventures' performance. In particular, this novelty is enforced by the adoption of the multicriteria research framework MUCRINE which has the ability to reveal the importance of each criterion and moreover elucidates the strategic actions that the entrepreneurs must implement. For the collection of the data, we used a structured questionnaire. The sectors and the representation of each sector in the sample are listed in Table 1.

Table 1. The allocation of the sample participants by sector of the creative industries.

\begin{tabular}{ccc}
\hline Creative Industries by Sector & Participants & \% in the Sample \\
\hline Art Gallery & 26 & 7.01 \\
\hline Architecture & 32 & 8.63 \\
\hline Graphic and Industrial Design & 39 & 10.51 \\
\hline Decoration & 27 & 7.28 \\
\hline Sculpture & 18 & 4.85 \\
\hline Publishing, Literature, Poetry & 27 & 7.28 \\
\hline Painting & 25 & 6.74 \\
\hline Media and Communication & 37 & 9.97 \\
\hline Theatre & 20 & 5.39 \\
\hline Film Production & 12 & 3.23 \\
\hline Music & 30 & 8.09 \\
\hline Games and Video games & 10 & 2.70 \\
\hline TV and Radio production & 14 & 3.77 \\
\hline Fashion & 54 & 14.56 \\
\hline
\end{tabular}

\section{Data Description}

The research was conducted in a sample of 371 women who exert entrepreneurial activity or are being self-employed in creative industries in Greece during the period of the years 2016 and 2017 (Table 2). 
Table 2. Demographics of the sample.

\begin{tabular}{|c|c|c|c|}
\hline Demographic Variables & Items & No. of Respondents & Percentage \\
\hline \multirow{5}{*}{ Age group } & $18-29$ & 75 & $20.2 \%$ \\
\hline & $30-40$ & 130 & $35 \%$ \\
\hline & $41-50$ & 77 & $20.8 \%$ \\
\hline & $51-60$ & 72 & $19.4 \%$ \\
\hline & $60+$ & 17 & $4.6 \%$ \\
\hline \multirow{5}{*}{ Years of entrepreneurial activity } & Less than a year & 20 & $5.4 \%$ \\
\hline & $1-4$ years & 128 & $34.5 \%$ \\
\hline & $5-10$ years & 97 & $26.1 \%$ \\
\hline & $11-20$ years & 72 & $19.4 \%$ \\
\hline & More than 20 years & 54 & $14.6 \%$ \\
\hline \multirow{6}{*}{ Family status } & $\begin{array}{l}\text { Single without } \\
\text { a child/children }\end{array}$ & 158 & $42.6 \%$ \\
\hline & $\begin{array}{l}\text { Single with } \\
\text { a child/children }\end{array}$ & 3 & $0.8 \%$ \\
\hline & $\begin{array}{l}\text { Married/engaged/in civil } \\
\text { partnership without } \\
\text { a child/ children }\end{array}$ & 44 & $11.9 \%$ \\
\hline & $\begin{array}{l}\text { Married/engaged/in civil } \\
\text { partnership with } \\
\text { a child/children }\end{array}$ & 129 & $34.8 \%$ \\
\hline & $\begin{array}{c}\text { Widowed/separated } \\
\text { without a child/ children }\end{array}$ & 7 & $1.9 \%$ \\
\hline & $\begin{array}{l}\text { Widowed/separated with } \\
\text { a child/ children }\end{array}$ & 28 & $7.5 \%$ \\
\hline \multirow{3}{*}{ Educational background } & Secondary education & 79 & $21.3 \%$ \\
\hline & Tertiary education & 162 & $43.7 \%$ \\
\hline & Master/PhD studies & 130 & $35 \%$ \\
\hline \multirow{2}{*}{$\begin{array}{l}\text { Origin from a family with } \\
\text { entrepreneurial background }\end{array}$} & Yes & 192 & $51.8 \%$ \\
\hline & No & 179 & $48.2 \%$ \\
\hline \multirow{2}{*}{$\begin{array}{l}\text { Origin from a family with } \\
\text { artistic background }\end{array}$} & Yes & 113 & $30.5 \%$ \\
\hline & No & 257 & $69.3 \%$ \\
\hline
\end{tabular}

The questionnaire is divided into two sections. The first section includes items for the evaluation of the respondents' network ties and the venture performance. All measures in this section used a seven-point Likert scale (e.g., $1=$ strongly disagree and $7=$ strongly agree). All scale reliabilities were acceptable, exceeding the acceptable value of 0.70, recommended by [19]. Particularly, the network ties construct was measured by using the scale developed by Chen et al. [20] consisting of four dimensions with four items in each one of them, namely, family, social, professional, and with the public sector. The Cronbach $\alpha$ for this scale was 0.87. An example item is "Participating in business communities of associations affords me advantages and leverage for dealing with business affairs well".

Venture performance was assessed by creating a new variable composed of two different existing scales. The first is the two-dimension scale of Wiklund and Shepherd [21], namely, financial performance and growth that appraise ventures performance in economic terms. An example item for this scale is "My activity's last three years' profitability is increasing, compared with my competitors in the same industry". The second is the three-dimensional scale of Chen et al. [20] developed to evaluate ventures creative performance in creative industries. Its dimensions are particularly firm creativity, social reputation, and career achievement, each of them consisting of four items. An example item 
of creative performance is "The work including business ideas, products, and the services that my firm produces are creative during the last three years" (firm creativity). The second section includes the demographic items of the sample.

\section{Methods}

\subsection{The Multicriteria Creative Industries Evaluation Method}

The MUlticriteria CReative INdustries Evaluation (MUCRINE) has been based on the Multicriteria Satisfaction Analysis method in order to provide quantitative measures of the creative industries performance considering the qualitative form of the entrepreneurs' judgements [22-28].

MUCRINE assesses global and partial performance functions $Y^{*}$, and $X_{i}^{*}$, respectively, given the entrepreneurs' judgments $Y$ and $X_{i}$. The ordinal regression analysis equation has the following form:

$$
\Upsilon^{*}=\sum_{i=1}^{n} b_{i} X_{i}^{*}-\sigma^{-}+\sigma^{+}
$$

where $Y^{*}$ and $X_{i}^{*}$ are monotone value functions normalized in the interval $[0,100], n$ is the number of criteria, $\sigma^{+}$and $\sigma^{-}$are the overestimation and the underestimation errors, respectively, and $b_{i}$ is the weight of criterion $i$, with $\sum_{i} b_{i}=1$.

As shown in Figure 1, for each value of the ordinal scale $Y$ the method assigns a cardinal value $Y^{*}$ (similarly, a cardinal value $X_{i}^{*}$ is assigned to each level of the ordinal scale $X_{i}$. Thus, contrary to a standard regression approach, both $Y^{*}$ and $X_{i}^{*}$ are unknown variables in Equation (1.1). Such an approach gives the ability to handle ordinal data without an arbitrary quantification of $Y$ and $X_{i}$. Moreover, introducing a double error variable gives the ability to adopt a goal programming approach. It should be noted that $\sigma^{+}, \sigma^{-}$have nonnegative values, while for the optimal solution we have $\sigma^{+} \cdot \sigma^{-}=0$, i.e., at least one of the errors should be zero for each respondent.

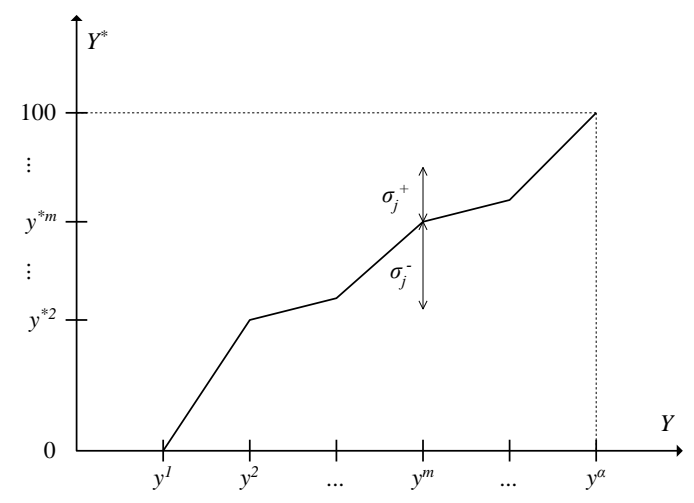

Figure 1. Error Variables for the $j$-th respondent.

The main objective of the method is to achieve the maximum consistency between the value function $Y^{*}$ and the individual judgements $Y$. Taking into account the previous assumptions and definitions, the estimation problem may be modeled as an optimization problem, where the objective is to minimize the sum of errors, under the following constraints: Equation (1) for each respondent, normalization and monotonicity constraints for $Y^{*}$ and $X_{i}^{*}$, non-negativity constraints for all variables. In order to linearize and reduce the size of the mathematical program, the following transformations are used:

$$
\begin{cases}z_{m}=y^{* m+1}-y^{* m} & \text { for } m=1,2, \ldots, a-1 \\ w_{i k}=b_{i} x_{i}^{* k+1}-b_{i} x_{i}^{* k} & \text { for } k=1,2, \ldots, a_{i}-1 \text { and } i=1,2, \ldots, n\end{cases}
$$

where $y^{* m}$ is the value of the $y^{m}$ ordinal level, $x_{i}^{* k}$ is the value to the $x_{i}^{k}$ ordinal level, $a, a_{i}$ are the number global and partial ordinal levels (i.e., the length of the $Y^{*}$ and $X_{i}^{*}$ ordinal scales). 
Based on the above, the basic estimation model can be written in a linear program formulation, as follows:

$$
\left\{\begin{array}{l}
{[\min ] F=\sum_{j=1}^{M} \sigma_{j}^{+}+\sigma_{j}^{-}} \\
\text {subject to } \\
\sum_{i=1}^{n} \sum_{k=1}^{t_{i j}-1} w_{i k}-\sum_{m=1}^{t_{j}-1} z_{m}-\sigma_{j}^{+}+\sigma_{j}^{-}=0 \forall j \\
\sum_{m=1}^{\alpha-1} z_{m}=100 \\
\sum_{i=1}^{n} \sum_{k=1}^{\alpha_{i}-1} w_{i k}=100 \\
z_{m} \geq 0, w_{i k} \geq 0, \sigma_{j}^{+} \geq 0, \sigma_{j}^{-} \geq 0 \forall i, j, k, m
\end{array}\right.
$$

where $M$ is the sample size (number of respondents), and $y^{j}, x_{i}^{j}$ are the $j$-th level on which variables $Y$ and $X_{i}$ are estimated. The weights $b_{i}$ and the value functions $Y^{*}, X_{i}^{*}$ are calculated based on the model variables $z_{m}$ and $w_{i k}$ (see [22] for details).

The model includes also a post optimality analysis stage in order to examine the problem of stability. The final solution is obtained by exploring the polyhedron of multiple or near optimal solutions, which is generated by the constraints of the previous linear program. More details on the mathematical development of the ordinal regression model may be found in [22]. Finally, the model also provides a series of fitting and stability indices for the reliability evaluation of the results. More specifically, the average fitting index (AFI) is calculated as the normalized sum of optimal errors, while the average stability index (ASI) is calculated as the average of the normalized standard deviation of the estimated weights. Both AFI and ASI are defined in [0,100], thus it is rather easy to evaluate the fitting and stability of the model (see [22] for more details).

\subsection{Results}

One of the most important actions for the decision makers to design and implement policies is the use of techniques in order to acquire the most competitive information against the competition. Based on the analysis of the data, the add value of the MUCRINE approach is the criteria weights. Analysing Figure 2, we observe that the most important criterion for the entrepreneurs is the criterion of professional networking that is in congruence with previous studies [29,30]. The least important criteria for the entrepreneurs are criteria such as the family network and the government networking, following the findings by Chen et al. [20]. It should be noted that the application of the MUCRINE approach in the previously presented sample resulted in the relative high fitting and stability indices $(\mathrm{AFI}=94.47, \mathrm{ASI}=97.54)$.

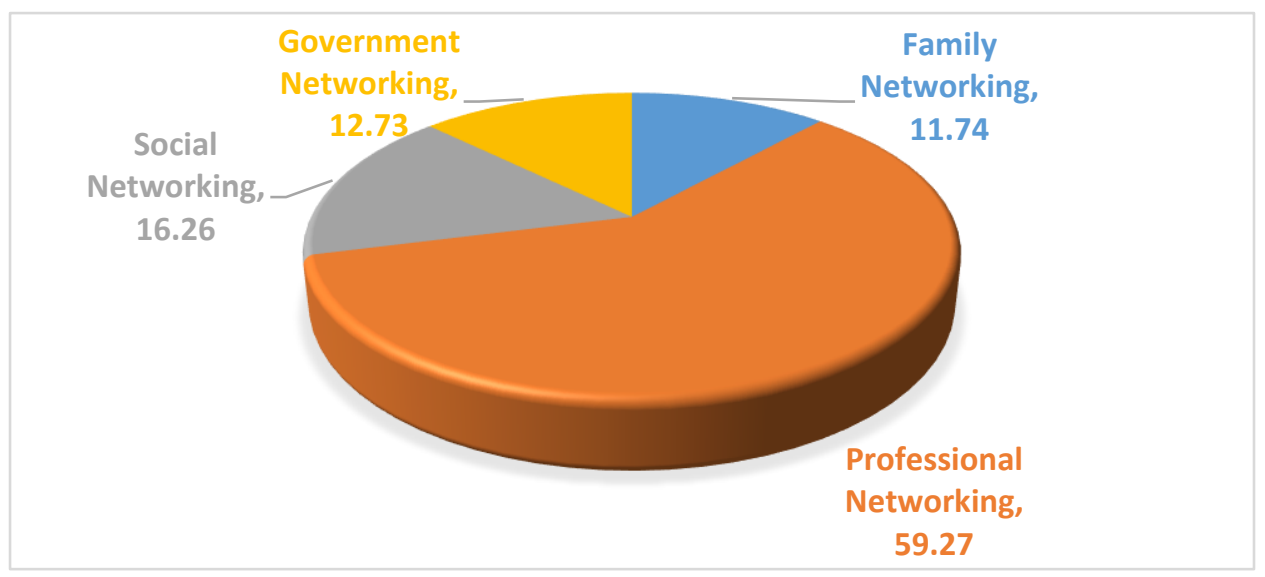

Figure 2. Criteria weights. 
In addition, the criteria weights of MUCRINE elucidates the actions diagrams that are similar to SWOT analysis. Based on these diagrams, the decision makers, in our case the entrepreneurs, can examine which are the weak and strong points of the firms' performance in the creative industries, based on the four types of networking. The action diagram (Figure $3 b$ ) is divided into four quadrants [22-28]: (i) Status quo (low performance and low importance): No action is required, given that these performance dimensions are not considered as important by the enterpreneurs, (ii) Leverage opportunity (high performance/high importance): This area can be used as advantage against the competition (creative industries), (iii) Transfer resources (high performance/low importance): A company's resources may be better used elsewhere, (iv) Action opportunity (low performance/high importance): These are the criteria that need attention; improvement efforts should be focused on them, in order to increase the performance of the creative industries.

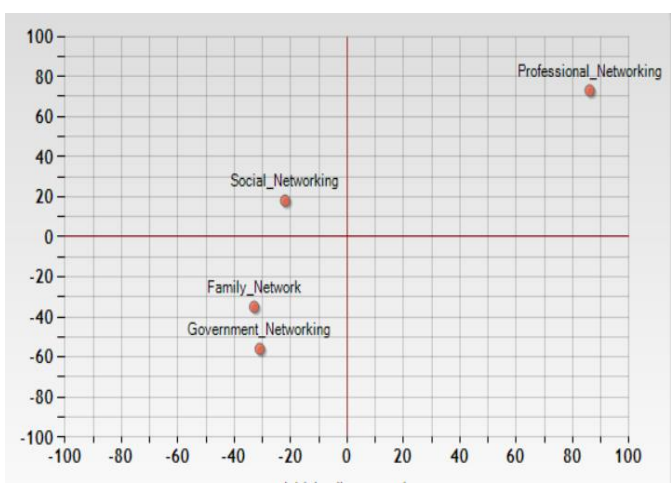

(a)

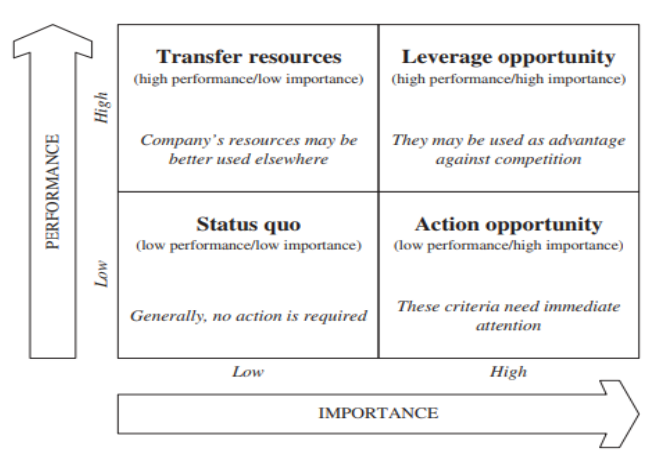

(b)

Figure 3. Action diagram.

As noted in the previous paragraph the action diagram depicts the strategic actions that the entrepreneurs should undertake and implement for the improvement of their ventures performance. More specifically in the area of "leverage opportunity" (Figure 3a), the entrepreneurs should rely more on professional networking because it exerts a crucial impact on performance, based on the criteria weights while the performance reveals a high value. It is worthy also to be mentioned that professional networking is the strategic advantage of the entrepreneurs against the competition. Moreover, in the area of "status quo", we observe the family network ties and network ties with the public sector, indicating that no action is required at this stage, given their limited impact on ventures' performance. On the other hand, the entrepreneurs are expected to improve the aforementioned network ties in the near future because their importance may be increased. Last but not least, social network ties are located in the "transfer resources" (Figure 3a) quadrant that are considered high, but the sample's female entrepreneurs do not view them as important in order to influence as a catalyst the venture performance.

\section{Conclusions}

This research unveils the importance of different types of networking in the area of firms' performance in the creative industries. The results and the dataset of this research are of critical interest both to the researchers and the practitioners of the creative industries as this work paves the way to adopt the appropriate networking practices for their firm's sustainability. This study is the first attempt to investigate the impact of different types of networking on firms' performance in creative industries. Likewise, the results of this research unveil which forms of networking, based on Chen et al. (2015) typology, are more preferable for women who exert entrepreneurial activity in creative industries in order to increase their ventures performance. These data can be compared with other data across the globe for the purposes of comparative analysis. Moreover, the existing data could induce more the scholars of the creative industries field to survey in depth the impact of networking on ventures' performance. Another significant contribution of this research is the development of a self-report 
construct of venture performance at the creative industries context based on economic and creative dimensions. Using the action diagrams of the MUCRINE framework, this study draws strategic actions for the creative industries entrepreneurs and researchers, and also networking practitioners.

Supplementary Materials: The following are available online at http://www.mdpi.com/2306-5729/5/1/24/s1. The data are submitted as a supplementary file. Excel: Data Descriptor_excel.

Author Contributions: Methodology, P.M., N.M., and E.G.; supervision, P.M. and N.M.; writing—original draft preparation: P.M., N.M., and E.G.; data analysis, P.M. and E.G. All authors have read and agreed to the published version of the manuscript.

Funding: This research received no external funding.

Acknowledgments: The authors are grateful to the female entrepreneurs for their active participation support in the survey.

Conflicts of Interest: The authors declare no conflict of interest.

\section{References}

1. Csikszentmihalyi, M. The creative personality. Psychol. Today 1996, 29, 36-40.

2. Matheson, B. A culture of creativity: Design education and the creative industries. J. Managem. Dev. 2006, 25, 55-64. [CrossRef]

3. Bridgstock, R. Not a dirty word: Arts entrepreneurship and higher education. Arts Human. H. Ed. 2013, 12, 122-137. [CrossRef]

4. Venturousaustralia: Building Strength in Innovation ('The Cutler Review'); Cutler \& Company Pty Ltd.: Williamstown, Australia, 2008. Available online: https://www.industry.nsw.gov.au/_data/assets/pdf_ file/0006/55383/NIS_review_Web3.pdf (accessed on 8 March 2020).

5. Parkman, I.D.; Holloway, S.S.; Sebastiao, H. How Art Meets Commerce: The Relationship Between Entrepreneurial Orientation And Firm Performance In The Creative Industries. In Proceedings of the 2011 Industry Studies Conference, Innovation and Entrepreneurship Research Stream, Munich, Germany, 2011.

6. Dervojeda, K.; Nagtegaal, F.; Lengton, M.; Datta, P. Creative Industries: Analysis of Industry-Specific Framework Conditions Relevant for the Development of World-Class Clusters; European Union: Brussels, Belgium, September 2013.

7. Aggestam, M. Art-Entrepreneurship in the Scandinavian Music Industry. Entrepreneurship in the Creative Industries-an International Perspective; Edward Elgar: Cheltenham, UK, 2007.

8. De Bruin, A. Multi-level entrepreneurship in the creative industries: New Zealand's screen production industry. Int. J. Ent. Innov. 2005, 6, 143-150. [CrossRef]

9. Buttner, E.H. Examining Female Entrepreneurs' Management Style: An Application of a Relational Frame. J. Bus. Ethics. 2001, 29, 253-269. [CrossRef]

10. Lau, S.; Li, W.-L. Peer Status and Perceived Creativity: Are Popular Children Viewed by Peers and Teachers as Creative. Creat. Res. J. 1996, 9, 347-352. [CrossRef]

11. Petridou, E. E-mentoring women entrepreneurs: Discussing participants' reactions. Gend. Manag. Int. J. 2009, 24, 523-542. [CrossRef]

12. Zhao, H.; Seibert, S.E.; Lumpkin, G.T. The Relationship of Personality to Entrepreneurial Intentions and Performance: A Meta-Analytic Review. J. Manage. 2010, 36, 381-404. [CrossRef]

13. Boso, N.; Story, V.M.; Cadogan, J.W. Entrepreneurial orientation, market orientation, network ties, and performance: Study of entrepreneurial firms in a developing economy. J. Bus. Ventur. 2013, 28, 708-727. [CrossRef]

14. Yiu, D.-W.; Lau, C.; Bruton, G.-D. International venturing by emerging economy firms: The effects of firm capabilities, home country networks, and corporate entrepreneurship. J. Int. Bus. Stud. 2007, 38, 519-540. [CrossRef]

15. Konrad, E.-D. Cultural Entrepreneurship: The Impact of Social Networking on Success. Creat. Innov. Manag. 2013, 20, 307-319.

16. Dana, L.-P.; Etemad, H.; Wright, R.W. Toward a paradigm of symbiotic entrepreneurship. Int. J. Entrep. Small Bus. 2013, 5, 109-126. [CrossRef]

17. Naudé, R.; Zaefarian, P.; Tavani, G.; Neghabi, Z.N.; Zaefarian, S. The influence of network effects on SME performance. Ind. Mark. Manag. 2014, 43, 630-641. [CrossRef]

18. Grabher, G. The project ecology of advertising: Tasks, talents and teams. Reg. Stud. 2002, 36, 245-262. [CrossRef] 
19. Nunnaly, J.C. Psychomettic Theory; Mcgraw-Hill College: New York, NY, USA, 1978.

20. Chen, M.H.; Chang, Y.Y.; Lee, C.Y. Creative entrepreneurs' guanxi networks and success: Information and resource. J. Bus. Res. 2015, 68, 900-905. [CrossRef]

21. Wiklund, J.; Shepherd, D. Entrepreneurial orientation and small business performance: A configurational approach. J. Bus. Ventur. 2005, 20, 71-91. [CrossRef]

22. Grigoroudis, E.; Siskos, Y. MUSA: Multicriteria Satisfaction Analysis; Springer: Boston, MA, USA, 2010. [CrossRef]

23. Siskos, Y.; Grigoroudis, E.; Matsatsinis, N.F. UTA methods. Int. Ser. Oper. Res. Manag. Sci. 2016, 233, 315-362. [CrossRef]

24. Siskos, Y.; Grigoroudis, E.; Matsatsinis, N.F. UTA methods. Int. Ser. Oper. Res. Manag. Sci. 2005, 297-343. [CrossRef]

25. Manolitzas, P.; Yannacopoulos, D. Citizen satisfaction: A multicriteria satisfaction analysis. Int. J. Pub. Adm. 2013, 36, 614-621. [CrossRef]

26. Manolitzas, P.; Grigoroudis, E.; Matsatsinis, N. Using multicriteria decision analysis to evaluate patient satisfaction in a hospital emergency department. J. Health Manag. 2014, 16, 245-258. [CrossRef]

27. Manolitzas, P.; Fortsas, V.; Grigoroudis, E.; Matsatsinis, N. Internal customer satisfaction in health-care organizations: A multicriteria analysis approach. Int. J. Pub. Adm. 2014, 37, 646-654. [CrossRef]

28. Manolitzas, P.; Kostagiolas, P.; Grigoroudis, E.; Intas, G.; Stergiannis, P. Data on patient's satisfaction from an emergency department: Developing strategies with the Multicriteria Satisfaction Analysis. Data Brief 2018, 21, 956-961. [CrossRef] [PubMed]

29. Butler, J.E.; Hansen, G.S. Network evolution, entrepreneurial success, and regional development. Entrep. Reg. Dev. 1991, 3, 1-16. [CrossRef]

30. Yuan, K.-H. Incomplete data analysis View project Multilevel modeling View project. Multivar. Behav. Res. 2005, 40, 115-148. [CrossRef] [PubMed]

(C) 2020 by the authors. Licensee MDPI, Basel, Switzerland. This article is an open access article distributed under the terms and conditions of the Creative Commons Attribution (CC BY) license (http://creativecommons.org/licenses/by/4.0/). 